\title{
STRATEGI PEMBERDAYAAN EKONOMI MASYARAKAT NELAYAN DI DESA MEUNASAH KEUDE KECAMATAN MESJID RAYA KABUPATEN ACEH BESAR
}

\author{
M. Yuzan Wardhana', T. Makmur², Alga Firnanda ${ }^{3}$ \\ ${ }^{1}$ Program Studi Agribisnis, Fakultas Pertanian Universitas Syiah Kuala Darussalam Banda Aceh \\ Email: yuzan@unsyiah.ac.id
}

\begin{abstract}
ABSTRAK
Penelitian ini bertujuan untuk merumuskan strategi pemberdayaan ekonomi masyarakat di Desa Meunasah Keude dengan menggunakan metode analisis SWOT dan QSPM. Hasil penelitian menunjukkan bahwa skor IFE (2.40) dan EFE (2.42) yang berarti faktor internal dan eksternal masih sangat lemah. Hal tersebut menunjukkan bahwa belum optimalnya pemanfaatan faktor internal dan eksternal yang ada di kampung nelayan tersebut. Hasil matriks SWOT didapatkan strategi pembaruan yang terbagi dalam 4 strategi utama yaitu (SO, WO, ST, dan WT). Sedangkan hasil analisis QSPM menunjukkan bahwa alternatif strategi utama yaitu strategi WO, dimana strategi tersebut merupakan prioritas yang harus diimplementasikan dalam peningkatan pemberdayaan ekonomi masyarakat nelayan di Desa Meunasah Keude. Dengan adanya alternatif tersebut diharapkan pemerintah serta stackholder lainnya dapat menjadi pelopor sekaligus penggerak dalam mendukung nelayan meningkatkan kehidupan ekonominya sehingga dapat hidup secara mandiri dan berkembang.
\end{abstract}

Kata Kunci: Nelayan, Pemberdayaan Ekonomi, SWOT, QSPM

\begin{abstract}
This study aims to formulate a strategy of community economic empowerment in the village of Meunasah Keude by using the SWOT and QSPM analysis methods. The results showed that the IFE score (2.40) and EFE (2.42), which means that internal and external factors are still very weak. This shows that the utilization of internal and external factors in the fishing village is not yet optimal. The SWOT matrix results obtained renewal strategies which are divided into 4 main strategies namely (SO,WO, ST, and WT). While the results of the QSPM analysis show that the main alternative strategy is the WO strategy, where the strategy is a priority that must be implemented in improving the economic empowerment of the fishing community in the village of Meunasah Keude. With this alternative, it is hoped that the government and other stackholders can become pioneers and movers in supporting fishermen to improve their economic lives thus that they can live independently and burgeon.
\end{abstract}

Keyword : Fishermen, Economic Empowerment, SWOT, QSPM 


\section{PENDAHULUAN}

Kabupaten Aceh Besar merupakan salah satu daerah yang terletak di pesisir provinsi aceh dengan panjang garis pantai $344 \mathrm{~km}$ serta luas area perairan lautnya adalah $2.796 \mathrm{Km} 2$. Selama kurun waktu 2011-2015 produksi perikanan tangkap di Kabupaten Aceh Besar cenderung meningkat dengan rata-rata pertumbuhan pertahun sebesar 13\% (BPS Aceh, 2016). Sehingga sektor perikanan merupakan salah satu sektor unggulan yang diharapkan dapat memberikan kontribusi bagi pembangunan dan kesejahteraan masyarakat. Dengan potensi yang begitu besar sehingga begitu banyak daerah di pesisir Aceh Besar yang memiliki potensi tersebut, salah satunya di kecamatan Mesjid Raya desa meunasah Keude, merupakan daerah yang terletak di tepi pantai dimana sebagian besar (80\%) masyarakatnya berprofesi sebagai nelayan.

Ironisnya, kekayaan dan potensi sumberdaya perikanan yang tersedia belum dapat mengangkat harkat dan kehidupan perekonomian masyarakat pesisir, khususnya nelayan. Paradoks kemiskinan nelayan (miskin di tengah kelimpahan sumber daya yang ada) merupakan hal yang terjadi disaat ini, tidak hanya di Meunasah Keude bahkan di Aceh ataupun Indonesia pada umumnya. Statistik menunjukkan bahwa pada tahun 2012, tingkat kemiskinan yang terjadi di Aceh adalah $19.46 \%$ dan $80 \%$ diantaranya merupakan yang berdomisili di pedesaan dengan mata pencarian utama yaitu nelayan dan petani (Pemerintah Aceh, 2013).

Hal tersebut dapat dijelaskan dengan kondisi masyarakat di desa meunasah keude yang belum mendapatkan kesejahteraan. Kondisi kesejahteraan keluarga di sana sebagian besar masih dalam kategori keluarga sejahtera I (137 Keluarga) yaitu keluarga yang kebutuhan dasarnya telah terpenuhi namun belum bisa memenuhi kebutuhan sosial.
Sesuatu yang paling memprihatinkan, masih banyaknya keluarga yang dalam kategori prasejahtera (96 keluarga) dimana kondisi ini merupakan belum dapat memenuhi kebutuhan dasarnya (basic need) secara minimal, seperti kebutuhan pangan, sandang, papan, kesehatan dan sebagainya. Lalu kategori petahapan keluarga sejahtera lainnya sejahtera II (133), sejahtera III (17) dan hanya 1 yang berkategori keluarga sejahtera IV (BPS Aceh Besar, 2018). Sumber daya perikanan merupakan penopang kehidupuan bagi masyarakat nelayan dalam meningkatkan taraf perekonomian dan terlepas dari jerat kemiskinan, diperlukannya perencanaan dan pengembangan yang erat kaitannya dengan pemberdayaan ekonomi. Sehingga strategi pemberdayaan ekonomi yang dihasilkan diharapkan akan mampu meminimalisir permasalahan yang terjadi selama ini. Pemberdayaan masyarakat yang dilakukan bukan semata-mata sebuah konsep ekonomi. Pemberdayaan masyarakat secara implisit memiliki pengertian menegakkan demokrasi ekonomi pada masyarakat dan kegiatan ekonomi yang berlangsung adalah dari rakyat, oleh rakyat dan untuk rakyat, (Mardikanto, 2015).

Hal ini mengingat pentingnya pemberdayaan ekonomi masyarakat nelayan dan tidak adanya studi sebelumnya yang mengangkat permasalahan mengenai pemberdayaan ekonomi nelayan. Maka penelitian ini bertujuan untuk merumuskan/ memformulasikan strategi pemberdayaan ekonomi pada masyarakat nelayan dan diharapkan bisa membantu serta meningkatkan kehidupan perekonomian dan permasalahan yang terjadi pada masyarakat nelayan Desa Meunash Keude, Kecamatan Mesjid Raya, Kabupaten Aceh Besar. 


\section{METODE PENELITIAN}

Penelitian ini dilakukan Desa Meunasah Keude, Kecamatan Mesjid Raya Kabupaten Aceh Besar. Pemilihan lokasi penelitian ini dilakukan secara sengaja mengingat Desa ini salah satu daerah pesisir pantai dan mayoritas masyarakatnya berprofesi sebagai nelayan. Penelitian ini menggunakan metode kualitatif dan kuantitatif (Mix-method). Menurut Tashakkori dan Teddlie (2010) metode mixmethod merupakan metode yang memadukan pendekatan kualitatif dan kuantitatif dalam hal metodologi dan kajian model campuran dengan memadukan dua pendekatan dalam semua tahapan proses penelitian.

Objek penelitian adalah masyarakat nelayan di Desa Meunasah Keude. Adapun ruang lingkup penelitian ini terbatas pada pemberdayaan ekonomi masyarakat nelayan di desa Meunasah Keude Kecamatan Mesjid Raya Kabupaten Aceh Besar. Data yang digunakan berupa data primer yang didapatkan dari wawancara dan kuisioner pada masyarakat nelayan desa meunasah keude serta menggunakan data sekunder. Varibael yang digunakan yaitu (1) faktor internal berupa kekuatan dan kelemahan dan (2) faktor eksternal berupa peluang dan ancaman.

Analisis data pada penelitian ini menggunakan model analisis SWOT (Strengths, Weakness, Opportunities, Threats) dan analisis QSPM (Quantitative Strategic Planning Matrix). Tahapannya berupa (1) tahap input dan pemasukan data, setelah data didapatkan data di input kedalam matrik IFE dan EFE lalu dilanjutkan dengan diagram analisis SWOT, (2). Tahap Pencocokan data, merupakan tahapan yang digunakan untuk menghasilkan alternatif strategi setelah mencocokkan faktorfaktor internal dan eksternal yang didapatkan dari tahapan sebelumnya sehingga dihasilkan matriks SWOT, dan (3) tahap Keputusan berupa matriks QSPM bertujuan untuk menentukan strategi yang paling tepat dengan kondisi masyarakat berdasarkan prioritas (David, 2006).

\section{HASIL DAN PEMBAHASAN}

Tabel 1. Hasil dari Matriks IFE (Internal Factor Evaluation) Pemberdayaan Ekonomi Masyarakat Nelayan di Desa Meunasah Keude

\begin{tabular}{ccccc}
\hline & FAKTOR & Bobot & Rating & $\begin{array}{c}\text { Skor } \\
\text { NO }\end{array}$ \\
& $\mathbf{x}$ \\
INTERNAL & Rating)
\end{tabular}

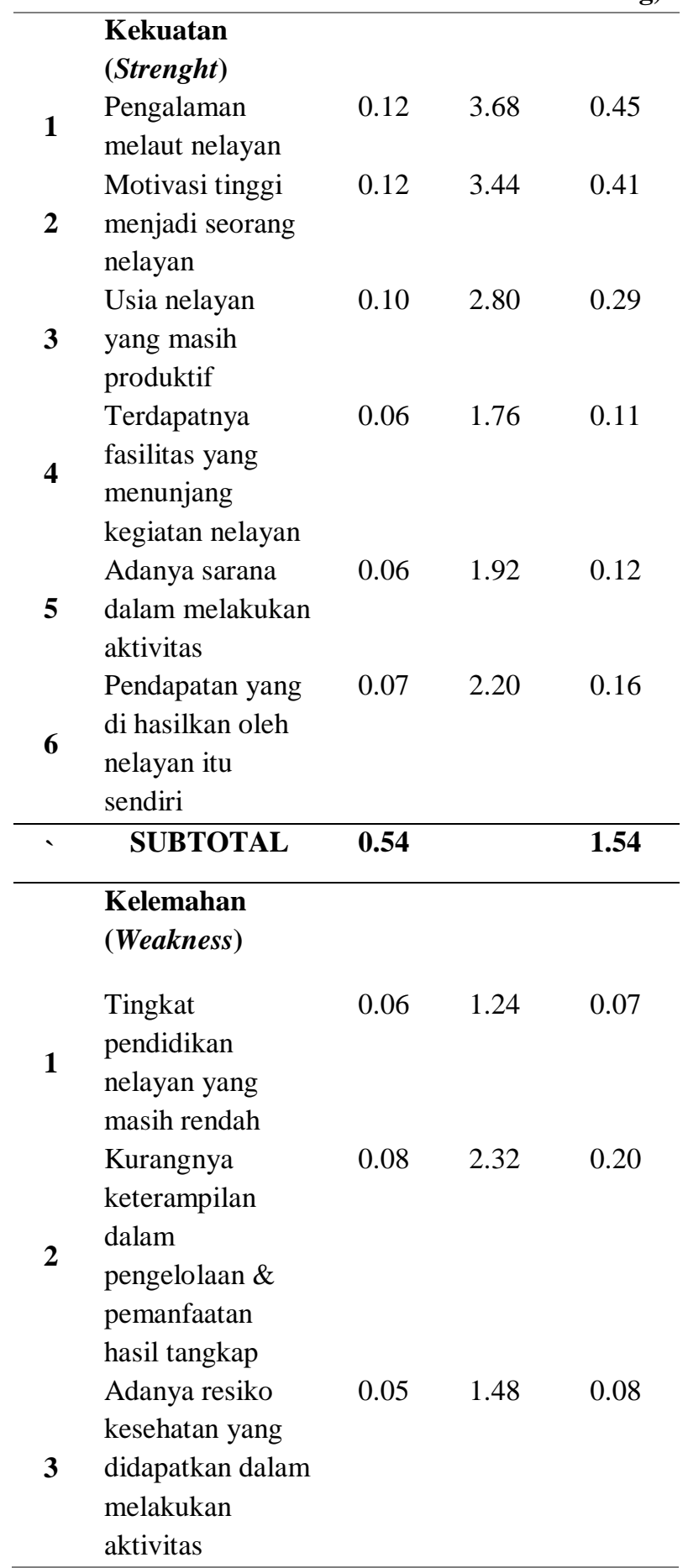


M.Yuzzan Wardhana, et all. Strategi Pemberdayaan...

\begin{tabular}{|c|c|c|c|c|}
\hline 4 & $\begin{array}{l}\text { Kurangnya } \\
\text { penggunaan } \\
\text { teknologi }\end{array}$ & 0.06 & 1.84 & 0.12 \\
\hline 5 & $\begin{array}{l}\text { Terbatasnya } \\
\text { modal yang } \\
\text { dimiliki }\end{array}$ & 0.05 & 1.36 & 0.07 \\
\hline 6 & $\begin{array}{l}\text { Kurangnya akses } \\
\text { informasi yang } \\
\text { didapatkan oleh } \\
\text { nelayan }\end{array}$ & 0.06 & 1.64 & 0.10 \\
\hline 7 & $\begin{array}{l}\text { Kurangnya } \\
\text { Motivasi untuk } \\
\text { menabung } \\
\text { pendapatan yang } \\
\text { diperoleh }\end{array}$ & 0.09 & 2.60 & 0.23 \\
\hline & SUBTOTAL & 0.46 & & 0.86 \\
\hline & $\begin{array}{c}\text { TOTAL SKOR } \\
\text { PEMBOBOTAN }\end{array}$ & 1.00 & & 2.40 \\
\hline
\end{tabular}

Tabel 2. Hasil dari Matriks EFE (Eksternal Factor Evaluation) Pemberdayaan Ekonomi Masyarakat Neayan di Desa Meunasah Keude.

\begin{tabular}{|c|c|c|c|c|}
\hline NO & $\begin{array}{c}\text { FAKTOR } \\
\text { EKSTERNAL }\end{array}$ & Bobot & Rating & $\begin{array}{c}\text { Skor } \\
\text { (Bobot } \\
\quad x \\
\text { Rating) }\end{array}$ \\
\hline & $\begin{array}{c}\text { Peluang } \\
\text { (Opportunities) }\end{array}$ & & & \\
\hline 1 & $\begin{array}{l}\text { Besarnya potensi } \\
\text { sumber daya } \\
\text { perikanan yang } \\
\text { tersedia }\end{array}$ & 0.10 & 3.20 & 0.33 \\
\hline 2 & $\begin{array}{l}\text { program } \\
\text { pemberdayaan } \\
\text { ekonomi pesisir } \\
\text { yang } \\
\text { dilaksanakan oleh } \\
\text { pemerintah }\end{array}$ & 0.07 & 2.08 & 0.15 \\
\hline 3 & $\begin{array}{l}\text { Dukungan dari } \\
\text { berbagai aturan } \\
\text { dan program } \\
\text { yang dikeluarkan } \\
\text { lembaga } \\
\text { panglima laot }\end{array}$ & 0.06 & 1.92 & 0.12 \\
\hline 4 & $\begin{array}{l}\text { Industri swasta } \\
\text { sektor perikanan } \\
\text { yang membantu } \\
\text { dalam kerja sama } \\
\text { usaha dan }\end{array}$ & 0.05 & 1.76 & 0.10 \\
\hline
\end{tabular}

\begin{tabular}{|c|c|c|c|c|}
\hline & $\begin{array}{l}\text { penampungan } \\
\text { hasil tangkap }\end{array}$ & & & \\
\hline 5 & $\begin{array}{l}\text { Tersedianya } \\
\text { pasar yang } \\
\text { memadai }\end{array}$ & 0.09 & 2.84 & 0.26 \\
\hline 6 & $\begin{array}{l}\text { Permintaan ikan } \\
\text { di pasar masih } \\
\text { sangat tinggi }\end{array}$ & 0.10 & 3.08 & 0.30 \\
\hline
\end{tabular}

\begin{tabular}{rrr}
\hline SUBTOTAL & 0.48 & 1.26 \\
\hline
\end{tabular}

Ancaman

(Threats)

1 Aturan

$\begin{array}{lll}0.07 & 2.28 & 0.15\end{array}$

pemerintah

mengenai batasan

dan larangan

dalam

pemanfaatan

sumberdaya

perairan

2 Kondisi iklim dan $\quad 0.05 \quad 1.12 \quad 0.05$

cuaca yang

berubah-ubah

sehingga dapat

pempengaruhi

aktivitas yang

dijalankan dan

hasil yang

didapatkan

3 Eksploitasi

$\begin{array}{lll}0.06 & 1.84 & 0.11\end{array}$

sumber daya

perairan

4 Penggunaan Alat

$\begin{array}{lll}0.05 & 1.24 & 0.06\end{array}$

Tangkap yang

tidak selektif

5 Terdapatnya

$\begin{array}{lll}0.05 & 1.64 \quad 0.08\end{array}$

selihih harga jual

yang sangat

tinggi antara

nelayan dan

konsumen akhir

$\begin{array}{lllll}6 & \text { Stok ikan yang } & 0.06 & 2.12 & 0.13\end{array}$

bisa saja habis

$\begin{array}{lllll}7 & \text { Kurangnya peran } & 0.06 & 2.04 & 0.13\end{array}$

masyarakat

dalam menjaga

kerukan

lingkungan laut

8 persaingan antar

$0.12 \quad 3.72$

0.43

nelayan

\begin{tabular}{|c|c|c|}
\hline SUBTOTAL & 0.52 & 1.16 \\
\hline $\begin{array}{c}\text { TOTAL SKOR } \\
\text { PEMBOBOTAN }\end{array}$ & 1.00 & 2.42 \\
\hline
\end{tabular}


Setelah melaksanakan penelitian dihasilkan 2 matriks yaitu Matriks Internal Factor Evaluation (IFE) dan Matriks Eksternal Factor Evaluation (EFE). Sebagai evaluasi terhadap faktor internal dan eksternal yang ada, pada matrik IFE (tabel 1) dihasilkan total skor pembobotan yaitu 2,40 yang menunjukkan bahwa faktor internal pemberdayaan ekonomi pada masyarakat nelayan Desa Meunasah Keude masih sangat lemah dan tidak efisien dalam pemanfaatannya. Hal ini diakibatkan karena belum optimal dalam pemanfaatan kekuatan yang ada serta belum bisanya meminimalkan pengaruh dari kelemahan yang tersedia.

Matrik EFE (Tabel 2) Menghasilkan total skor pembobotan yaitu 2.42 maka disimpulkan faktor eksternal pemberdayaan ekonomi masyarakat nelayan Desa Meunasah Keude sangat lemah dan tidak efisien dalam pemanfaatannya. Hal ini dikarenakan belum optimal dalam pemanfaatan peluang yang ada, serta belum bisa meminimalkan pengaruh dari ancaman yang tersedia.

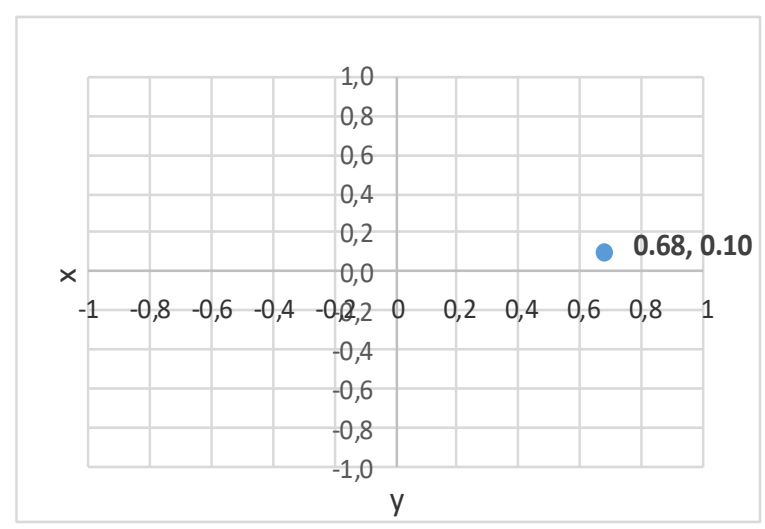

Gambar 1. Hasil dari Analisis Diagram SWOT Pemberdayaan Ekonomi Masyarakat Nelayan Gampong Meunash Keude

Diagram pada gambar 1 menghasilkan bahwa posisi pemberdayaan ekonomi masyarakat meunasah keude berada pada kuadran 1 (kuadran agresif). Hal ini menunjukkan bahwa faktor kekuatan dan peluang masih tersedia dan masih dapat dimanfaatkan semaksimal mungkin, sehingga strategi yang nantinya dihasilkan adalah penerapan strategi pertumbuhan pemberdayaan ekonomi masyarakat meunasah keude secara agresif (Growth Oriented Strategy).

Analisis Matriks SWOT (Strengths Weakness Opportunities Threats) bertujuan untuk merumuskan alternatif strategi pengembangan pada pemberdayaan ekonomi masyarakat nelayan gampong Meunasah Keude, Kecamatan Mesjid Raya Kabupaten Aceh Besar dengan mamadukan antara hasil yang telah didapatkan dari matrik IFE (Internal Factor Evaluation) dan matriks EFE (Eksternal Factor Evaluation). Matrik SWOT dapat dilihat pada tabel 3, sebagai berikut:

Tabel 3. Hasil analisis matriks SWOT Pemberdayaan ekonomi masyarakat nelayan di gampong Meunasah Keude (rumusan alternatif stratetegi pembaruan yang dihasilkan)

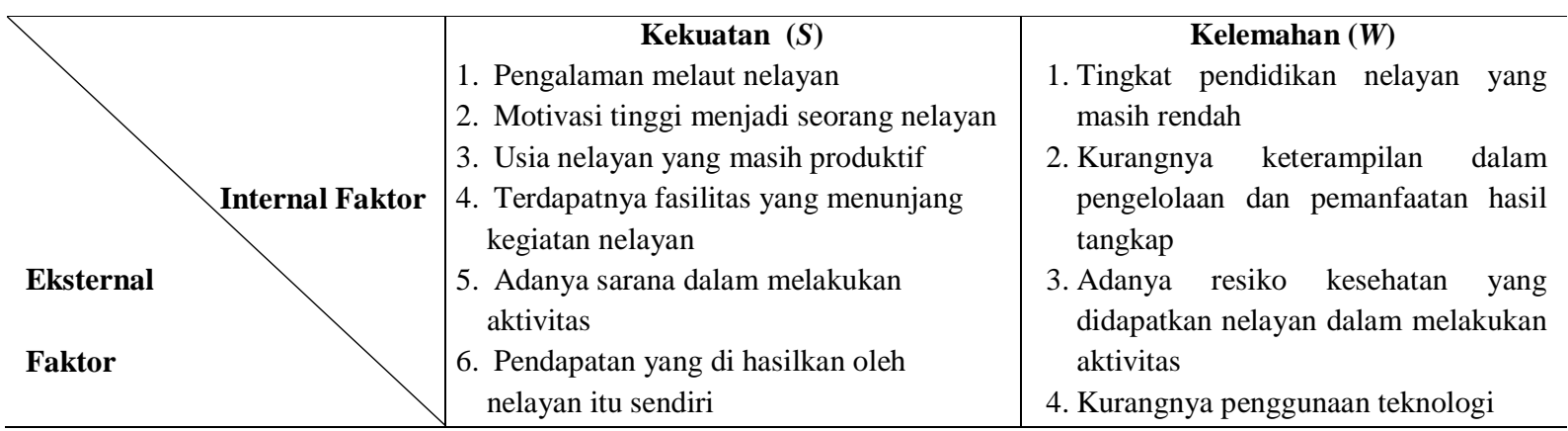




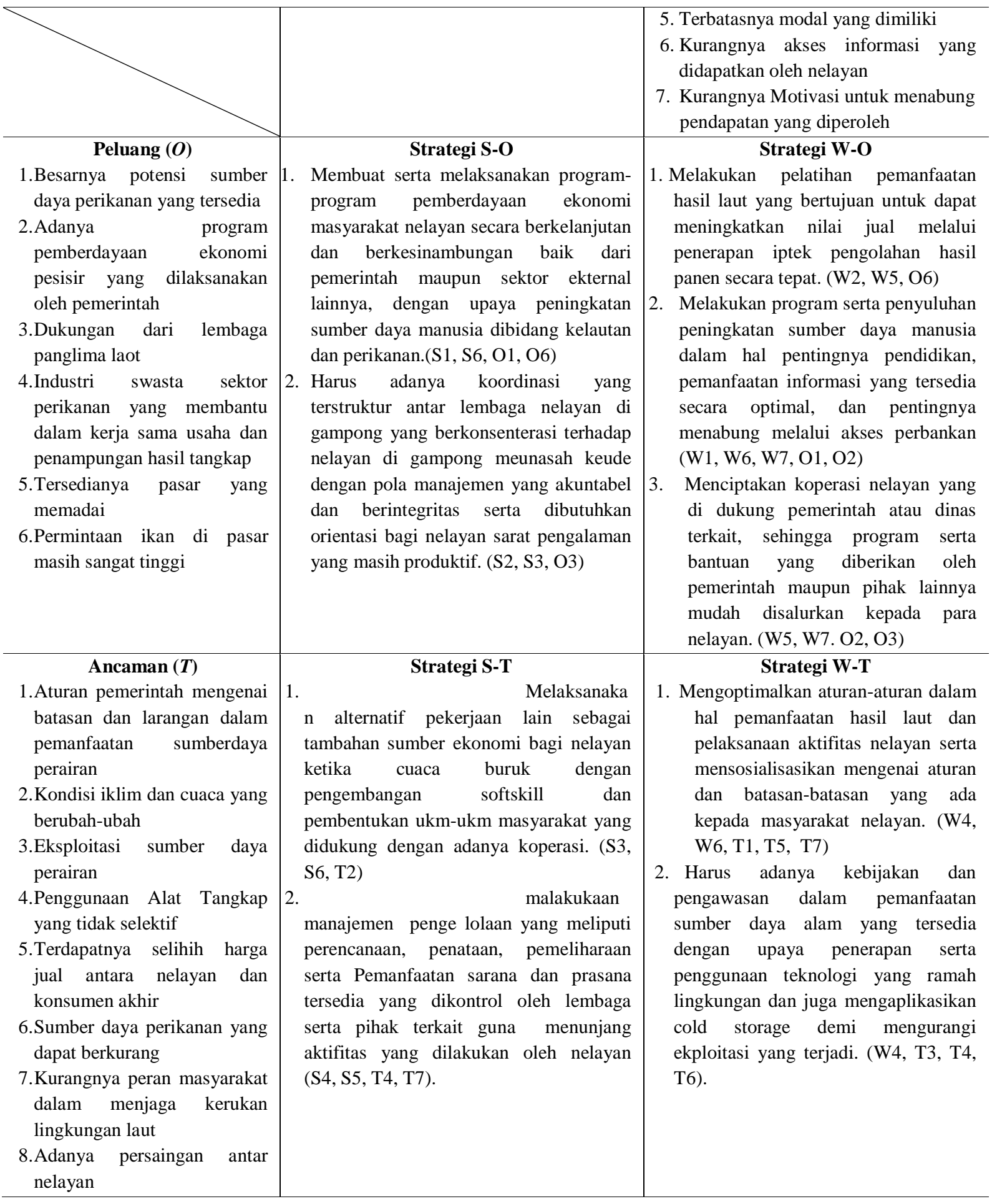

Hasil penelitian melalui model analisis SWOT merumuskan 4 (empat) alternatif strategi dalam upaya peningkatan dan pengoptimalan pemberdayaan ekonomi masyarakat nelayan di desa Meunasah Keude, yaitu sebagai berikut:

\section{Strategi $\mathrm{S}-\mathrm{O}$}

- Membuat serta melaksanakan programprogram pemberdayaan ekonomi masyarakat nelayan secara berkelanjutan dan berkesinambungan baik dari pemerintah maupun sektor ekternal lainnya, dengan upaya peningkatan sumber daya manusia dibidang kelautan dan perikanan

- Harus adanya koordinasi yang terstruktur antar lembaga nelayan di desa yang berkonsenterasi terhadap nelayan di desa meunasah keude dengan pola manajemen 
yang akuntabel dan berintegritas serta dibutuhkan orientasi bagi nelayan sarat pengalaman yang masih produktif.

2. Strategi $W-O$

- Melakukan pelatihan pemanfaatan hasil laut yang bertujuan untuk dapat meningkatkan nilai jual melalui penerapan iptek pengolahan hasil panen secara tepat.

- Melakukan program serta penyuluhan peningkatan sumber daya manusia dalam hal pentingnya pendidikan, pemanfaatan informasi yang tersedia secara optimal, dan pentingnya menabung melalui akses perbankan.

- Menciptakan koperasi nelayan yang di dukung pemerintah atau dinas terkait, sehingga program serta bantuan yang diberikan oleh pemerintah maupun pihak lainnya mudah disalurkan kepada para nelayan.

\section{Strategi $S-T$}

- Melaksanakan alternatif pekerjaan lain sebagai tambahan sumber ekonomi bagi nelayan ketika cuaca buruk dengan pengembangan softskill dan pembentukan ukm-ukm masyarakat yang didukung dengan adanya koperasi.

- Melakukaan manajemen pengelolaan yang meliputi perencanaan, penataan, pemeliharaan serta Pemanfaatan sarana dan prasana tersedia yang dikontrol oleh lembaga serta pihak terkait guna menunjang aktifitas yang dilakukan oleh nelayan.

\section{Strategi $W-T$}

- Mengoptimalkan aturan-aturan dalam hal pemanfaatan hasil laut dan pelaksanaan aktifitas nelayan serta mensosialisasikan mengenai aturan dan batasan-batasan yang ada kepada masyarakat nelayan.

- Harus adanya kebijakan dan pengawasan dalam pemanfaatan sumber daya alam yang tersedia dengan upaya penerapan serta penggunaan teknologi yang ramah lingkungan dan juga mengaplikasikan cold storage demi mengurangi ekploitasi yang terjadi.
Tabel 4. Matriks Hasil QSPM (Quantitative Strategic Planning Matrix) Pemberdayaan Ekonomi Masyarakat Nelayan di Gampong Meunasah Keude (menentukan prioritas terhadap alternatif strategi yang dihasilkan matriks SWOT).

\begin{tabular}{lcc}
\hline $\begin{array}{c}\text { Alternatif } \\
\text { Strategi }\end{array}$ & STAS & Prioritas \\
\hline Strategi I (S-O) & 4.45 & 3 \\
Strategi II (W-O) & 4.80 & 1 \\
Strategi III (S-T) & 4.59 & 2 \\
Strategi IV (W-T) & 4.43 & 4 \\
\hline
\end{tabular}

Hasil analisis QSPM Menunjukkan bahwa prioritas utama alternatif strategi yang harus diimplementasikan dalam pemberdayaan ekonomi nelayan gampong Meunash Keude yaitu strategi II (W-O) Sedangkan prioritas selanjutnya yaitu Prioritas kedua, Strategi III (S-T) nilai Stas 4.59 dan prioritas ketiga serta keempat yaitu Strategi I (S-O) dan IV (W-T) dengan nilai Stas berurutan 4.45 dan 4.43 . Dalam hal ini pelaksanaan strategi yang dihasilkan tidak bisa dilakukan sekaligus dimana pemberdayaan harus dilakukan secara bertahap dan berkesinambungan demi mendapatkan hasil yang efektif. Analisis QSPM ini menunjukkan tahapan-tahapan pelaksanaan alternatif strategi pemberdayaan masyarakat nelayan Gampong Meunasah Keude yang telah dihasilkan melalui hasil analisis SWOT, dimana tahapan ini ditunjukkan melalui prioritas yang harus dilaksanakan. Tahapan pertama yaitu mengimplementasikan alternatif W-O yang menjadi prioritas 1 , strategi didalamnya berupa pengembangan, peningkatan dan pemandirian masyarakat melalui 3 strategi yaitu 1). melakukan Pelatihan pemanfaatan hasil laut yang bertujuan untuk dapat meningkatkan nilai jual melalui penerapan iptek pengolahan hasil panen secara tepat, 2). melakukan program serta penyuluhan pengingkatan sumber daya manusia dalam hal pentingnya pendidikan, pemanfaatan informasi yang tersedia secara optimal dan pentingnya menabung melalui akses perbankan, dan 3). menciptakan koperasi nelayan yang di dukung pemerintah atau dinas terkait, sehingga 
program serta bantuan yang diberikan oleh pemerintah maupun pihak lainnya mudah disalurkan kepada para nelayan.

\section{KESIMPULAN}

Penguatan serta pemanfaatan faktor internal dan eksternal yang tersedia di masyarakat nelayan desa meunasah keude masih sangat rendah. Dalam hal ini faktor kekuatan dan peluang yang tersedia belum dapat dioptimalkan, sedangkan faktor kelemahan dan ancaman yang ada dapat diminimalkan pengaruhnya. Hal ini menjadi permasalahan utama yang terjadi pada nelayan dimana jika ditangani secara individu akan sulit untuk terpecahkan. Oleh karena itu diperlukan strategi pemberdayaan ekonomi yang bisa menjadi solusi dalam meningkatkan kesejahteraan dan keaadaan ekonomi masyarakat nelayan. Dengan menggunakan matriks SWOT didapatkan 9 strategi yang terbagi kedalam 4 alternatif (S-O, W-O, S-T, dan W-T) serta menggunakan analisis QSPM dapat ditentukan empat tahapan implementasi prioritas alternatif strategi yang dimulai dengan strategi W-O dan dapat dilaksanakan oleh masyarakan serta pihak-pihak terkait. Dengan adanya alternatif tersebut diharapkan pemerintah serta stackholder lainnya dapat menjadi pelopor sekaligus pengerak dalam mendukung nelayan meningkatkan taraf ekonominya sehingga dapat hidup secara mandiri dan berkembang.

\section{DAFTAR PUSTAKA}

BPS Aceh. (2016). Bandar Aceh Dalam Angka.

BPS Aceh Besar. (2018). Kecamatan Mesjid Raya Dalam Angka.

David, F. R. (2006). Manajemen strategis. Edisi Sepuluh, Penerbit Salemba Empat, Jakarta.

Mardikanto. (2015). Pemberdayaan Masyarakat Dalam Perspektif Kebijakan Publik. Bandung: Alfabeta.
Pemerintah Aceh. (2013). Qanun Aceh no 12.

Tashakkori, A., \& Teddlie, C. (2010). Mixed Methodology Mengombinasikan Pendekatan Kualitatif dan Kuantitatif, terj. Budi Puspa Priadi. Yogyakarta: Pustaka Pelajar.

T. d. C. T. Abbas, Mixed Methodologi (Mengkombinasikan Pendekatan Kualitas dan Kuantitas), Yogyakarta: Pustaka Belajar, 2010.

V. E. d. S. D. Selatan S., "Strategi Pemberdayaan Masyarakat Nelayan Soma Pajeko di Kecamatan Salibabu Kabupaten Kepulauan Talaud Sulawesi Utara," Jurnal Sosek KP, pp. 87-97, 2018.

S. R. S. d. W. Pangestoeti, "Pemberdayaan Masyarakat Nelayan di Desa Air Payang Kecamatan Pulau Laut Kabupaten Natuna," Program Studi Administrasi Publik Fakultas Ilmu Sosial dan Ilmu Politik Universitas Maritim Raja Ali Haji, pp. 118, 2018.

S. M., "Analisis Pemberdayaan Masyarakat Nelayan di Kecamatan Tobelo Kabupaten Halmahera Utara," IPB, Bogor, 2010.

M. Yusuf, "Pemberdayaan Ekonomi Masyarakat Nelayan Berbasis Komunitas Ibu Rumah Tangga Desa Karang Agung," in National Conference on Economic Education, Malang, 2016. 